\title{
A Model for Technology Assessment and Commercialization For Innovative Disruptive Technologies
}

\author{
Suleiman K. Kassicieh and Steve Walsh, Anderson Schools Of Management, \\ University Of New Mexico, Albuquerque, NM 87131 \\ Al Romig, John Cummings, Paul McWhorter, and David Williams, Sandia \\ National Laboratories, Albuquerque, NM 87185
}

\section{Introduction}

Disruptive technologies are scientific discoveries that break through the usual product/technology capabilities and provide a basis for a new competitive paradigm as described by Anderson and Tushman [1990], Tushman and Rosenkopf [1992], and Bower and Christensen [1995]. Discontinuous innovations are products/processes/services that provide exponential improvements in the value received by the customer much in the same vein as Walsh [1996], Lynn, Morone and Paulson [1996], and Veryzer [1998]. For more on definitions of disruptive technologies and discontinuous innovations, see Walsh and Linton [1999] who provide a number of definitions for disruptive technologies and discontinuous innovations.

Disruptive technologies and discontinuous innovations present a unique challenge and opportunity for R\&D organizations seeking to build their commercialization efforts and to reinvent the corporation. These technologies do not have a proven path from scientific discovery to mass production and therefore require novel approaches. These critically important technologies are the wellspring of wealth creation and new competency generation but are not readily accepted by the corporate community. They are alternatively embraced and eschewed by the commercial community. They are finally accepted when the technology has already affected the industry or when "the technological horse has already flown out of the hanger." Many firms, especially larger firms, seem reluctant to familiarize themselves with these technologies quickly. The trend seems to be that these firms prefer to react to a proven disruptive technology that has changed the product market paradigm. If true, then there is cause for concern.

This paper will review the literature on disruptive technologies presenting a model of the progression from scientific idea to mass production for disruptive technologies contrasted to the more copious incremental technologies. The paper will then describe Sandia National Laboratories' involvement in one of the disruptive technology areas, namely micro-electromechanical systems (sometimes referred to as Microsystems or MEMS) and will survey a number of companies that have investigated Sandia's technological discoveries for potential use in an industrial capacity. The survey will focus on the movement of the research findings from the laboratory into the marketplace and all of the problem areas that disruptive technologies face in this arena. The paper will then state several hypotheses that will be tested. The data will be described with results and conclusions reported.

\section{Literature on Disruptive Technologies}

What are they? There are numerous differing arguments for the exact definitions of either disruptive technologies or discontinuous innovations. Disruptive technologies can be considered scientific discoveries that break through the usual product'technology capabilities and provide a basis for a new competitive paradigm. Discontinuous innovations can be considered products/processes/services that provide exponential improvements in the value received by the customer. Disruptive technologies have been referred to as inflection point, earthquake, game breaking, whirlwind, typhoon or emergent technologies. The nomenclature is not important but the phenomena have become increasingly important to firms. No longer the domain of entrepreneurial firms, disruptive technologies change the current product-technology paradigms. These paradigms are replaced by new manufacturing bases with new technological capabilities or by new technologies with a new manufacturing base for products and industries that do not yet exist. They initiate the development of new firm-based competencies and are the wellspring of future sustaining technologies. Discontinuous innovations have been called radical, architectural, generational and revolutionary among many others. They are often based on disruptive technologies but can also be the product of current sustaining 


\section{DISCLAIMER}

This report was prepared as an account of work sponsored by an agency of the United States Government. Neither the United States Government nor any agency thereof, nor any of their employees, make any warranty, express or implied, or assumes any legal liability or responsibility for the accuracy, completeness, or usefulness of any information, apparatus, product, or process disclosed, or represents that its use would not infringe privately owned rights. Reference herein to any specific commercial product, process, or service by trade name, trademark, manufacturer, or otherwise does not necessarily constitute or imply its endorsement, recommendation, or favoring by the United States Government or any agency thereof. The views and opinions of authors expressed herein do not necessarily state or reflect those of the United States Government or any agency thereof. 


\section{DISCLAIMER}

Portions of this document may be illegible in electronic image products. Images are produced from the best available original document. 
technologies that produce higher value propositions. They provide step-function improvements to current product market paradigms or produce the physical and service products that initiate new industries or markets that define a new and differing product platform from which incremental innovations are generated.

Tushman, Anderson and O'Reilly [1997], for example, presented the idea of a technology cycle where technological discontinuities, substitution of technologies, dominant designs and incremental change are part of an iterative technology cycle. This cycle implies that firms need to have organizations that have dual responsibilities: maintain the current production system with small incremental changes while at the same time look for the major breakthroughs. The "ambidextrous" organization allows the firm to bring in the resources at the same time building new products. Anderson and Tushman [1990] had developed the idea of discontinuities and their relationship to dominant designs. Amy Glasmeier [1991] presented the effect that a new discontinuous innovation, quartz technology, had on the mechanical movement Swiss watch industry.

Christensen [1997] presented the case for the hard drive manufacturers and how incremental innovations and sustaining technologies were not sufficient for survival when new disruptive technologies were leapfrogging the price/performance parameters of these incremental innovations.

Rice, O'Connor, Peters and Morone [1998] reported on a joint project with the Industrial Research Institute (IRI) where 11 projects in 9 companies were designated as "breakthrough" technologies. The focus of the project was to understand the management of high risk projects associated with commercializing discontinuous innovations. Projects with a 5-10 times improvement in performance, $30-50 \%$ reduction in cost, and/or new-to-the-world performance were defined as "breakthrough" discontinuous innovations. An example of the companies and products used in the project is General Electric and its digital X-ray. The projects had common mechanisms such as definition of a "holy grail", establishment of venture boards, internal requests for proposals and scanning for ideas by groups and individuals.

Isenberg [1999] presents one of the examples of a major distuption in the area of telecommunications. He postulates that if the $64 \mathrm{Kbps}$ channel is a one-lane highway, then the optical transmissions of dense wavelength division multiplexors (DWDM) at 40Gbps will represent a $12-$ million lane highway.

Kaplan [1999] presents strategies to take advantage of disruptive technologies. These strategies include radical cannibalism by replacing one's own successful products with new products that represent significant value increase for customers. Another strategy is competitive displacement where you replace your competitors' products with new significantly higher value-added products. The other two strategies are industry genesis where you start new industries and market invention where you create new demand.

Abernathy and Clark [1985] used industry wide product-technology factors to define disruptive technologies. Mckee [1992] used the gap between substitutable technological learning curves on cost or performance basis as the indicator of the existence of disruptive technologies. Moore [1995] used customer behavior to describe discontinuous innovation whereas Carroad and Carroad [1982] used product novelty. Lambe and Spekman used market factors to describe it and Lynn, Morone and Paulson [1996] used a combination of these factors. Moore clarifies this aspect of disruptive technologies by noting that they generate discontinuous innovations that require users/adopters to change their behavior in order to use the innovation. Moore argues that the performance attributes of the innovation must overcome "newness" resistance of customers. Such resistance may be based upon issues of reliability and quality consistency. Summaries of the perspectives of these various authors are shown in Table 1.

Florida and Kenney [1990] argue that prior to the 1980 's, America was noted for the ability of its firms to develop new ideas and new products. Unfortunately, they note, America continued to develop great ideas but was unable to bring many of these products to market. The disappointing performance of US firms in technology intensive markets such as consumer electronics, robotics, automobiles and semiconductor memories has been widely attributed to a failure to continuously and incrementally improve products and processes.

Christensen [1997] uses the hard disk computer memory industry to validate his observation that management emphasis has shifted from discontinuous innovation to continuous or incremental innovation. He states that most large firms neglect discontinuous innovations and focus their resources on incremental change or continuous improvement. However, he argues, incremental innovation is insufficient for sustained competitive advantage. 


\section{Commercialization Models and Models for Disruptive Technology}

Commercialization of technologies depends to a large extent on a number of factors:

1) The nature of the technology: sustaining or disruptive

2) The size of the company: small firm or large firm

3) The source of the technology: internal or external to the firm.

4) The strategic intent of the firms

The nature of the technology affects the market knowledge available to the firm. Sustaining technologies have defined existing markets and the firm is usually looking to enhance its products, processes or services to increase its profitability and/or market share. The risk, then, faced in sustaining technology development is much less than disruptive technologies where the uncertainty about the use of the product, process or service and/or the reaction of the market to it is unknown. This uncertainty leads technology commercialization experts to suggest a careful approach that utilizes as many of the mechanisms of technology transfer as possible since that allows many different experiments with different participants and potential users.

Small entrepreneurial firms have been a driving force behind the commercialization of disruptive technologies. Birch [1987], Kirchhoff and Phillips [1988], and Reynolds [1987] indicate that a majority of jobs in high-technology are created by the small firms. These firms are more agile and are better able to deal with uncertainty than larger firms. Large firms have also responded to the challenge of starting new areas of business. Cooper and Smith [1992] describe how firms that have a well-established product behave when a new technology threatens the dominance of their established product. In some cases, they conclude, the establishment of a new division to handle the new technology is warranted. Christensen points out that HP's experience with the ink jet and the laser jet where the two competing technologies were managed by two separate divisions netted a positive result. Digital Equipment's management of the personal computer and the minicomputer from the same division led to failure in the personal computer market and eventually to Digital's problems.

Models of commercialization of products that substitute for existing products have been used for small and large firms. Kassicieh and Radosevich [1994] present many of the mechanisms used for technology transfer and commercialization from public-sector research organizations. The major implication for technology transfer and commercialization is that the more channels of communications that exist between the technology source and the technology recipient, the more likely will the technology find its way to the market. This model might be the necessary ingredient for disruptive technology since the high level of uncertainty attached to new-to-the-world technologies requires trial in many different industries and many different products.

Commercialization models depend on a variety of issues that define a market focus for product development or on a technology development perspective that develops new markets. These two foci depend on the existence of the following elements:

1) scientific discovery

2) applications

3) products

4) government supportbuyers

5) commercial support/suppliers/buyers

6) distribution channels

7) research support for new discoveries

8) research support for new applications

9) research support for new products

10) buyers/market

11) real market growth

12) perceived/potential market growth

This paper will test how these parameters influence the planning of disruptive technologies and the creation of new products in the marketplace.

\section{R\&D Organizations}

Sandia National Laboratories has long been in the business of developing advanced technologies for the security of the nation. Sandia's stewardship of their "High Tech" capabilities has helped to bring safety, security and affluence to our nation. Sandia has a history of providing commercially essential technologies to emergent critically important industries. One example of this is the Sandia development of laminar flow engineering for the emergent semiconductor microfabrication community [Ref.]. Sandia early efforts were singular in nature but as the lab has matured so has the manner in which they steward their "High Tech" capabilities. Sandia, long at the forefront of deriving value from what are today identified as disruptive technologies, is developing certain concepts and procedures that address the critical issue of creating value centered on distuptive technologies.

Sandia as a world class R\&D facility faces the challenge of managing rapidly changing and 
interactive technologies and products. These technologies, although "high tech" in nature, are not all disruptive. We here bifurcate them into sustaining technologies and disruptive technologies. Sustaining technologies follow a more continuous improvement market-focused (Phillips [199x]) process and are applied to internal and external customer problems that intensify rather than create new lab competence. Sustaining technologies can be planned according to a technological roadmap and add value to an industrial value chain.

Disruptive technologies, on the other hand, follow a more discontinuous innovation path requiring a market-development rather than a marketfocused approach. When deriving value from these technologies, the exact placement of the disruptive technology in an existing industry value chain is not clear. Technological roadmaps are very hard to construct for these technologies since the contribution to the industrial value chain is murky and the products are not so obvious. Traditional market focus forces provide little aid in these areas.

Most firms, when faced with creating competitive advantage from disruptive technologies, revert back to an internally driven approach which can be successful but has a history of generating marketing myopia, NIH syndrome and the like. Sandia, however, perhaps due to the nature of the national labs where competency generation and creation is the more natural stock and trade, has initiated what we call a market development approach.

Since the market-focused approach and the internally driven approach have been around and are easily applied to technologies where markets and customers exist, a new approach is needed for disruptive technologies. This approach needs to provide companies in many application areas and totally unrelated fields with a way to experiment with the new technologies to determine how they can assist in developing new products that diverge from the traditional demand for the company's products.

This process is open to large and small companies alike (see history of competitive advantage from small companies), etc.

\section{Hypothesis}

Our hypothesis in this paper can be stated as "commercialization activities required for products based on disruptive technologies differ significantly from commercialization of products based on improvement technologies."

\footnotetext{
Sandia is a multipnom laboratory

operated by Sandia Corporation. a

Lockheed Martin Company, for the

United States Department of Energy

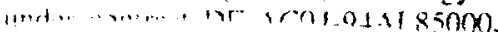

\section{References}

Abernathy, W. J., and Clark, K. B., "Innovation: Mapping the Winds of Creative Destruction" Research Policy, 1985, 14, pp. 3-22.

Anderson, P. and Tushman, M. "Technological Discontinuities and Dominant Designs: A Cyclical Model of Technological Change," Administrative Science Quarterly, 1990, 35(6), 604-633.

Birch, D. L. Job Creation in America: How Our Small Companies Put the Most People to Work. New York: Free Press, 1987.

Bower, J. L., and Christensen, C. M., "Disruptive Technologies: Catching the Wave." Harvard Business Review, 1995, 73(1), pp. 43-53.

Carroad, P. and C. Carroad, "Strategic Interfacing of R\&D and Marketing." Research Technology Management January 25:1 (1982), pp. 28-33.

Christensen, C. The Innovator's Dilemma: When New Technologies Cause Great Firms to Fail. Boston: Harvard Business School Press, 1997.

Cooper, Arnold C. And Smith, Clayton G., "How Established Firms Respond to Threatening Technologies", The Academy of Management Executive, 1992, 6(2).

Ehrenberg, E., "On the Definition and Measurement of Technological Discontinuities." Technovation, 15:7 (1995), pp. 437-452.

Florida, R., and M. Kenney, The Breakthrough Illusion, New York: Basic (1990).

Foster, R. N., Innovation: The Attacker's Advantage, New York: McKinsey and Company (1986).

Glasmeier, Amy, "Technological Discontinuities and Flexible Production Networks: the Case of Switzerland and the World Watch Industry," Research Policy, 1991, 20(5), 469-485.

Isenberg, David S., " The Mother of All Disruptions", America's Network, 1999, 103(11), 12.

Kaplan, Soren M., "Discontinuous Innovation and the Growth Paradox," Strategy \& Leadership, 1999, 27(2), 16-21. 
Kassicieh, S. K. and Radosevich, R. "The Participant Roles In Public-Sector

Technology Commercialization," in Suleiman K. Kassicieh and H. Raymond Radosevich (eds.) From Lab to Market: Commercialization of Public-Sector Technology. N.Y.: Plenum Publishing, 1994, pp. 125-135.

Kirchhoff, B. A. and Phillips, B. D., "The effect of firm formation and growth on job creation in the United States" Journal of Business Venturing, 1988, 3, 261-272.

Lambe, C., and R. E. Spekman, "Alliances, External Technology Acquisition, and Discontinuous Technological Change." Journal of Product Innovation Management, 14:2 (1997), pp. 102-116.

Lynn, G., Morone, J. and Paulson, A., "Marketing and discontinuous innovation: The Probe and Learn Process." California Management Review, 1996, 38(3), pp. 8-37.

Mckee, D., "An Organizational Learning Approach to Product Innovation" Journal of Product Innovation Management 9:3 (1992), pp. 232-245.

Meyers, P., and F. Tucker," Defining Roles for Logistics During Routine and Radical Technological Innovation." Journal of the Academy of Marketing Sciences, 17:1 (1989), pp. 73-82.

Rice, Mark P.; O'Connor, Gina C.; Peters, Lois S. and Morone, Joseph G., "Managing Discontinuous Innovations," Research Technology Management, 1998, 41(3), 52-58.

Radosevich, R. and Kassicieh, S., "Strategic challenges to competitiveness through public-sector technology," California Management Review, 1993 , 35(4), 33-50.

Reynolds, P. D. New firms: societal contribution versus survival potential. Journal of Business Venturing, 1987, 2, 231-246.

Tushman, Michael L. ; Anderson Philip C. And O'Reilly, Charles, "Technology Cycles, Innovation Streams, Ambidextrous Organizations: Organizational Renewal Through Innovation Streams and Strategic Change," in Tushman and Anderson (eds.) Managing Strategic Innovation and Change. N.Y.: Oxford University Press, 1997.
Tushman and Rosenkopf

Veryzer, R., "Discontinuous Innovation and the New Product Development Process." The Journal of Product Innovation Management, 1998, 15(4), pp. 304-321.

Walsh, S., "Commercialization of MicroSystems Too Fast or Too Slow." SPIE, The International Society for Optical Engineering, 1996, pp. 12-26. 